\title{
와트 $\mathrm{Ni}$ 도금욕에서 도금 피막에 미치는 $\mathrm{Al}, \mathrm{Al}_{2} \mathrm{O}_{3}$ 분산제 및 열처리의 영향
}

\author{
이상백 ${ }^{\dagger}$ 박형호* · 배인성* · 윤재식* · 김병일** \\ 자동차부품 및 소재연구개발센터 \\ *회유금속 소재 연구소 \\ **순천대학교 재.료 · 금속공학과
}

\section{Effect of $\mathrm{Al}, \mathrm{Al}_{2} \mathrm{O}_{3}$ Dispersants and Heat Treatment on Deposits from Watt's Ni Plating Bamth}

\author{
Sang Baek Lee ${ }^{\dagger}$ Hyung Ho Park*, In Sung Bae*, Jae Sik Yoon* and Byung Il Kim** \\ Research and Development Center for Automobile Parts and Materials \\ * Korea Research Institute of Rare Metals \\ **Material Science and Metallurgical Engineering, Sunchon National University
}

(2002년 1월 24일 받음, 2002년 2월 19일 최종수정본 받음)

\begin{abstract}
The co-deposited behavior was investigated under varied bath compositions and current densities from Watt $\mathrm{Ni}$ plating bath containing $\mathrm{Al}$ and $\mathrm{Al}_{2} \mathrm{O}_{3}$ powders. For single-particle bath, $\mathrm{Al}$ and $\mathrm{Al}_{2} \mathrm{O}_{3}$ particles were agglomerated. The area percentage of $\mathrm{Al}_{2} \mathrm{O}_{3}$ on plating surface decreased with increasing the current density, while that of $\mathrm{Al}$ on plating surface increased. On the other hand, in case of double-particle bath with $1.25 \mathrm{~g} / \ell$ of $\mathrm{Al}$ and $5.0 \mathrm{~g} / \ell$ of $\mathrm{Al}_{2} \mathrm{O}_{3} 5 \mathrm{~g}$, the area percentage of $\mathrm{Ni}-\mathrm{Al}-\mathrm{Al}_{2} \mathrm{O}_{3}$ increased with increasing current density and the surface morphology was fine without agglomeration. Intermetallic compounds such as $\gamma^{\prime}$ and $\gamma+\gamma^{\prime}$ phases appeared when the co-deposited film was annealed.
\end{abstract}

Key words: The co-deposited behaviour, agglomeration, intermetallic compounds, $\underline{\mathrm{Ni}-\mathrm{Al}-\mathrm{Al}_{2} \mathrm{O}_{3}}$

1. 서 론

전기화학방법을 이용한 분산 · 복합재의 연구개발이 급속 히 증가함에도 불구하고, 상당수의 방법은 전통적인 전착법 에 집중되어 있다. 이러한 이유는 전착법에 의해서 포괄적 인 연구가 가능하기 때문이다. 최근까지 " $\mathrm{Ni}$ 전해욕+ 분산 입자" 형태의 $\mathrm{Ni}$-분산도금이 이 분야에서 가장 많은 연구 결과를 도출해 냈다. 그 이유는 전해, 무전해 모두 전착력 및 레벨링 (levelling) 특성이 우수하여 분산 입자의 적옹 범위가 큰 장점을 가지고 있기 때문이다. 이외에 $\mathrm{Ni}$ 도금은 색이 좋고, 비교적 변색도 적으며 경도가 우수하다. 또한 기계적 성질도 양호할 뿐만 아니라 방청력도 큰 특성을 가 지고 있다. ${ }^{1)} \mathrm{Ni}$ 분산도금은 복합 Ni도금 (composite $\mathrm{Ni}$ plating)으로도 불리운다. 또한 고체 입자나 오일 캡슐과 같은 물에 불용성 액체의 미립자 ( $1 \mu \mathrm{m}$ 이하) 를 도금액에 분 산시켜서 도금이 될 때 같이 흡착되면서 미립자가 흡장되기 때문에 흡장도금 (occlusion plating) 이라고도 한다.

또한 복합이라고 하면 2 종류 이상의 성분을 말하는 것으 로서 $\mathrm{Ni}$ 도금충에 이들 부도체들이 분산, 석출되어 있으면 그 위에 $\mathrm{Cr}$ 도금을 했을 때 부도체의 미립자가 있는 부분은
도금이 되지 않고 구멍이 생기게 되므로 미세공 $\mathrm{Ni}$ 도금 (microporous $\mathrm{Ni}$ plating) 이라고 한다. 분산도금의 공석 기구는 분산입자의 상호힘과 흡착 이온에 의해서 결정된다. 또한 분산도금 조업은 분산입자의 물성, 분산량, 입자의 입 도, $\mathrm{pH}$, 교반 정도 및 전류밀도에 의해서 크게 영향을 받는 것으로 알려지고 있다. ${ }^{2)}$ 분산도금이 생산 라인에 적용될 경 우에는 도금탱크의 여과기 문제, 침전 문제 등에 대한 적용 여부를 고려해야 한다. 또한 유기 분산제는 전해질과 접촉 하는 양극을 오염시킬 우려가 있으며 무기재료 입자, 특히 입자가 큰 분말들은 도금층내에 침지 되고, 응집화 현상 등 에 의해 도금충 두께가 증가된다.

이러한 복합도금재가 다른 부품과 접촉되어 사용되는 경 우, 도금재와 같이 사용되는 부품이 입자들에 의해 손상을 입을 가능성도 있다. 이와 같은 여러 문제를 해결하기 위해 분산도금충의 톡성은 물론 분산도금 프로세스에 대한 많은 연구가 필요하다. 그러나 국내에서는 분산도금 분야가 아직 초보 단계이고 단일 분산계외에는 분산도금에 대한 고찰이 부족한 상태이다. 따라서 본 연구에서는 와트 (Watt) $\mathrm{Ni}$ 도 금욕에 $\mathrm{Al}$ 과 $\mathrm{Al}_{2} \mathrm{O}_{3}$ 분말을 분산시켜 $\mathrm{Ni}$ 기지와의 공석 거 동과 열처리 후의 조직 변화를 관찰하였다.

†E-mail: snake123@dreamwiz.com 


\section{2. 실 험 방 법}

본 실험에서 사용된 음극 시편 (냉연강판, $\mathrm{POSCO}, 1 \mathrm{t}$ ) 은 $10 \mathrm{~mm} \times 20 \mathrm{~mm}$ 로 절단하여 사용하였다. 도금부 반대면 과 구리선을 납땜하여 연결하고, 도금면을 제외하고는 에폭 시계 수지(E. Dox. E. Steel Filter No. EPS-1) 로 절연, 피복처리 하였다. 음극은 다음과 같은 순서로 전처리를 하 였다.

i) \#400 2000순의 연마 후에 버프(buff) 연마

ii) 초음파 세척

iii) 수세 후 $\mathrm{NaOH} 12 \mathrm{~g} / \ell, \mathrm{Na}_{2} \mathrm{O}_{3} 11 \mathrm{~g} / \ell$ 의 혼합 탈 지액에서 5 분간 탈지 $\left(50^{\circ} \mathrm{C}\right)$

iv) 수세 후 $\mathrm{H}_{2} \mathrm{SO}_{4} 10 \%$ 로 10 초간 산세

v) 수세 후 건조

기본 $\mathrm{Ni}$ 도금욕 조성과 실험 조건을 Table 1 에 나타냈다.

실험에 사용된 와트 $\mathrm{Ni}$ 도금욕은 레벨링 톡성과 전착력 이 우수하기 때문에 문헌을 참조하여 본 실험에 적용하였 다. ${ }^{12)}$ Table 2 는 전해욕에 분산 될 $\mathrm{Al}, \mathrm{Al}_{2} \mathrm{O}_{3}$ 분말들의 특 성을 나타낸 것이다.

이 분말들을 $\mathrm{Ni}$ 도금욕에 각각 $0.5 \mathrm{~g} / \ell \sim 5 \mathrm{~g} / \ell$ 범위로 분산시켰다. 분산제를 도금욕에 가한 후, 예비 교반은 5 분 이내로 하고 도금을 개시하였다. 실헙에 사용된 전해전원은 직류-정전류 공급기 (Metronix, Model 592c) 를 사용하고 전류계 (FLUKE 8050A) 로 보정하였다. 통전 전기량은 쿨 롱미터 (Hokuto Denko, HF201) 로 계측하였다. 도금조는 음극실과 양극실이 석영 필터로 분리된 $500 \mathrm{~m} \ell$ 용량의 유리 제였다. 음극과 양극간의 거리는 $20 \mathrm{~mm}$ 로 고정하였으며, 욕 온도를 일정하게 유지하기 위해 항온조를 사용하였다.

열처리에 의한 도금층의 조직변화를 관찰하기 위해 제조 된 도금시편을 온도 조절이 3 영역으로 분리된 관상로에서 $600{ }^{\circ} \mathrm{C}, 10 \% \mathrm{H}_{2}+\mathrm{N}_{2}$ 분위기로 $1 \sim 30$ 시간 동안 열처리를 실시하였다. 도금 표면에 부착된 입자 면적점유율 및 표면, 단 면 양상은 상분석기 (Image Analyzer : Toshiba/Optical

Table 1. Electroly tic conditions for $\mathrm{Ni}-\mathrm{Al}-\mathrm{Al}_{2} \mathrm{O}_{3}$ dispersion plating

\begin{tabular}{l|l}
$\mathrm{NiSO}_{4} \cdot 6 \mathrm{H}_{2} \mathrm{O}$ & $225 \sim 300 \mathrm{~g} / \ell$ \\
$\mathrm{NiCl}_{2} \cdot 6 \mathrm{HO}_{2} \mathrm{O}$ & $53 \sim 60 \mathrm{~g} / \ell$ \\
$\mathrm{H}_{3} \mathrm{BO}_{3}$ & $35 \sim 40 \mathrm{~g} / \ell$ \\
Sulfree $80(\mathrm{~N} .25235)$ & $100 \mathrm{~m} \ell / \ell$ \\
$\mathrm{pH}$ & $4.0( \pm 0.5)$ \\
Temperature & $50^{\circ} \mathrm{C}\left( \pm 0.2^{\circ} \mathrm{C}\right)$ \\
Agitation speed & $450 \mathrm{r} . \mathrm{p} . \mathrm{m}$ \\
Current density & $1 \sim 20 \mathrm{~A} / \mathrm{dm}^{2}$ \\
\hline
\end{tabular}

Table 2. The properties of $\mathrm{Al}$ and $\mathrm{Al}_{2} \mathrm{O}_{3}$ powders used

\begin{tabular}{l|l}
\hline \multicolumn{1}{c|}{$\mathrm{Al}_{2} \mathrm{O}_{3}$} & \multicolumn{1}{|c}{$\mathrm{Al}$} \\
\hline Particle size $: 0.03 \mu \mathrm{m}$ & \\
Purity : 99.99\% & Particle size : $1 \sim 4 \mu \mathrm{m}$ \\
Impurity levels : Max. Si 25, Fe & Purity : 99.4\% \\
19, $\mathrm{Mg} \mathrm{4,} \mathrm{Cu} \mathrm{1(ppm)}$ & \\
\hline
\end{tabular}

Microscope) 를 이용하여 조사하였다. 도금충의 표면 형상 관찰을 위해 주사전자현미경 (SEM: JSM-6400) 및 X선 회절장치 (RIGAKU/USA, model D/max-111A) 을 사용 하였다. X 선 회절분석은 구리 타겟을 이용하여 $40 \mathrm{kV}$, $30 \mathrm{~mA}$ 에서 분당 $4^{\circ}$ 의 주사 속도 조건이었다.

\section{3. 결과 및 고찰}

\section{$3.1 \mathrm{Al}, \mathrm{Al}_{2} \mathrm{O}_{3}$ 입자의 면적점유율}

Fig. 1은 Ni 도금욕에 $\mathrm{Al}$ 분말을 분산시켰을 때, 분산량 과 전류밀도 변화에 따른 도금충 표면에서 $\mathrm{Al}$ 입자들의 면 적 점유율을 나타넨 것이다.

전류밀도 $15 \mathrm{~A} / \mathrm{dm}^{2}$ 조건에서 $\mathrm{Al}$ 이 $0.5 \mathrm{~g} / \ell, 1.25 \mathrm{~g} / \ell$ 분산된 경우 면적점유율의 증가가 다소 지연되었다. 이 외 에는 전류밀도 및 첨가량이 증가할수록 도금충 표면에서 $\mathrm{Al}$ 면적점유율도 증가하였다. 전류밀도 $1 \mathrm{~A} / \mathrm{dm}^{2}$ 에서는: 10 $\sim 20 \%$ 인 반면, $20 \mathrm{~A} / \mathrm{dm}^{2}$ 에서는 $74 \sim 85 \%$ 의 면적점유율 을 나타냈다. 또한 모든 조건에서 $\mathrm{Al}$ 분산량이 증가함에 따 라 면적점유율도 증가하였으며 전류밀도가 증가할수략 이 러한 경향이 뚜렷하였다.

Fig. 2 는 $\mathrm{Ni}$ 도금욕에 $\mathrm{Al}_{2} \mathrm{O}_{3}$ 분말을 분산시켰울 때, 분 산량과 전류밀도 변화에 따른 도금층 표면에서 $\mathrm{Al}_{2} \mathrm{O}_{3}$ 입자 들의 면적 점유율을 나타낸 것이다.

$\mathrm{Ni}$ 도금욕에 $\mathrm{Al}_{2} \mathrm{O}_{3}$ 을 분산시킨 경우에는 전류밀도가 증

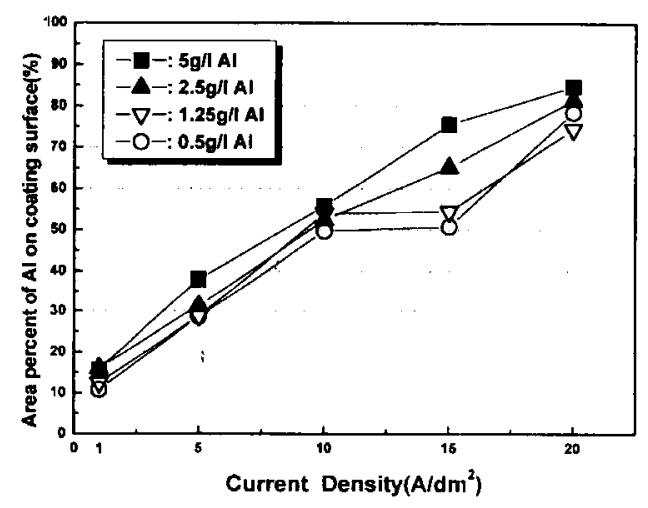

Fig. 1. Area percentage of $\mathrm{Al}$ on coating surface as a function of current density and $\mathrm{Al}$ bath loading

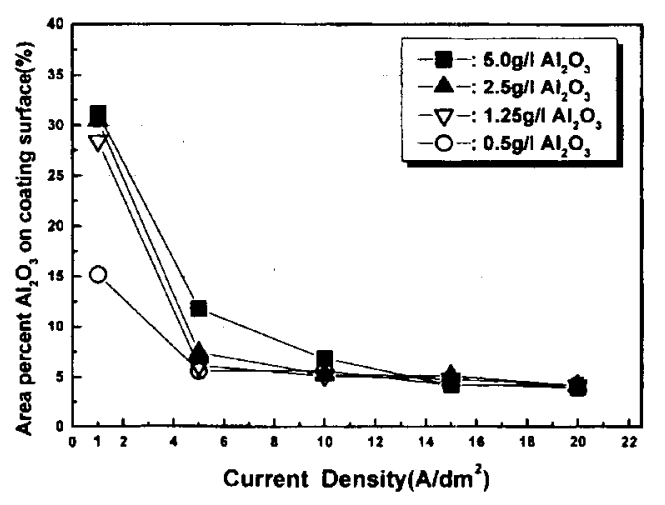

Fig. 2. Area percentage of $\mathrm{Al}_{2} \mathrm{O}_{3}$ on coating surface as a function of current density and $\mathrm{Al}_{2} \mathrm{O}_{3}$ bath loading 

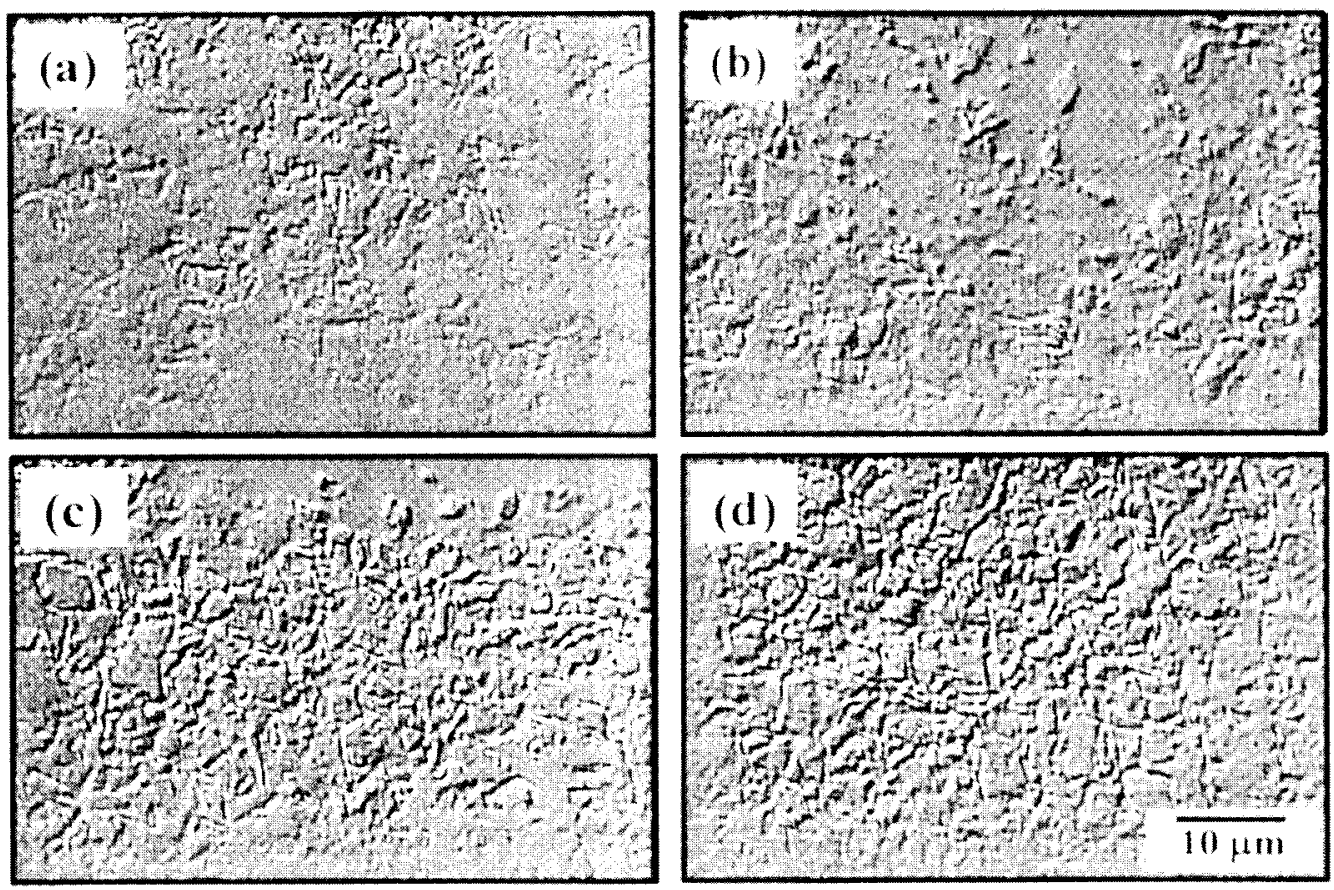

Fig. 3. Microscopic photographs (using image analyzer) of the coating surface with current density in the bath containing $5.0 \mathrm{~g} / \ell$ of $\mathrm{Al} \mathrm{(a)} 1 \mathrm{~A} / \mathrm{dm}^{2}$ (b) $10 \mathrm{~A} / \mathrm{dm}^{2}$ (c) $15 \mathrm{~A} / \mathrm{dm}^{2}$ (d) $20 / \mathrm{dm}^{2}$

가함에 따라 면적 점유율이 감소하였다. 이는 Fig. 1 의 Al 과는 반대의 경향을 나타내는 것이다. 전류밀도 $1 \mathrm{~A} / \mathrm{dm}^{2}$ 조건에서는 $15 \sim 33 \%, 20 \mathrm{~A} / \mathrm{dm}^{2}$ 에서는 $5 \%$ 정도의 $\mathrm{Al}_{2} \mathrm{O}_{3}$ 면적 점유율을 나타냈다. 이와 같이 전류밀도 증가에 따라 $\mathrm{Al}_{2} \mathrm{O}_{3}$ 의 면적점유율이 감소하는 이유는 $\mathrm{Al}$ 과 같은 도체는 전류와 비례하여 음극에 부착되지만, $\mathrm{Al}_{2} \mathrm{O}_{3}$ 와 같은 부도체 는 전류밀도가 중가에 따라 $\mathrm{Ni}$ 전착이온과 $\mathrm{Al}_{2} \mathrm{O}_{3}$ 와의 상호 간섭 및 방해 작용이 중가하기 때문이다. 또한 $1 \mathrm{~A} / \mathrm{dm}^{2}$ 의 조건에서는 $\mathrm{Al}_{2} \mathrm{O}_{3}$ 분산량에 따라 면적 점유율이 변화하였 으나, 전류말도가 증가할수록 $\mathrm{Al}_{2} \mathrm{O}_{3}$ 분산량이 큰 영향을 받 지 못했다. 이 역시 전착이온과 분산제와의 상호 방해작용 때문이다.

저전류밀도에서는 부도체인 $\mathrm{Al}_{2} \mathrm{O}_{3}$ 입자가 전기영동 (electrophoresis) 효과나 교반과 같은 기계적 힘에 의해서 도 음극 표면 부착이 가능하다. ${ }^{2 \sim 6)}$ 이러한 결과는 기존 연 구 결과 ${ }^{2,4}$ 와 잘 일치하고 있다. Fig. 1 과 Fig. 2 의 Al, $\mathrm{Al}_{2} \mathrm{O}_{3}$ 면적 점유율은 $\mathrm{Celis}^{2)}$ 등의 $\mathrm{Cu}-\gamma \mathrm{Al}_{2} \mathrm{O}_{3}$ 분산도금 및 $\mathrm{Ding}^{5)}$ 등의 $\mathrm{Ni}-\alpha \mathrm{Al}_{2} \mathrm{O}_{3}$ 와 $\mathrm{Cu}-\alpha \mathrm{Al}_{2} \mathrm{O}_{3}$ 분산도금과 거의 유사한 경 향을 나타냈으나, $\mathrm{Barmak}^{3)}$ 등의 연구결과와는 면적 점유 율에서 차이가 발생하였다. 이는 분산량, 도금욕 조성 $(\mathrm{Ni}$ 염의 종류, $\mathrm{Ni}$ 농도, $\mathrm{H}_{3} \mathrm{BO}_{3}$ 의 양) 차에 기인하는 것으로 생 각된다.

Fig. 3 은 $\mathrm{Ni}$ 도금욕에 $\mathrm{Al}$ 분말을 $5.0 \mathrm{~g} / \ell$ 조건으로 분 산시켰을 때 전류밀도에 따른 도금 표면 형상을 상분석기로 관찰한 것이다.

Fig. 1의 결과와 같이 전류밀도에 따라 Al의 표면 부착 이 증가했다. 반면 $\mathrm{Al}$ 의 미세 입자들이 균일하게 부착되지 않고 덩어리져서 부착되는 응집 (agglomeration) 현상이 관
찰되었다. Fig. 4는 $\mathrm{Ni}$ 도금욕에 $\mathrm{Al}_{2} \mathrm{O}_{3}$ 분말을 $5.0 \mathrm{~g} / \ell$ 조 건으로 분산시켰을 때 전류밀도에 따른 도금 표면 형상을 상분석기로 관찰한 것이다.

Fig. 2의 결과와 같이 전류밀도 증가에 따라서 $\mathrm{Al}_{2} \mathrm{O}_{3}$ 의 표면 부착이 감소했으며 $\mathrm{Al}$ 과 같이 응집화된 부착 양상이 관찰되었다. 응집현상의 주원인은 분말 형태의 분산제이기 때문으로 여겨진다. 특히 $\mathrm{Al}_{2} \mathrm{O}_{3}$ 의 경우는 부도체로서 저전 류밀도에서 전기영동이나 교반력 등에 의해 음극에 취약하 게 부착되기 때문에 균일한 부착을 기대할 수 없다. 이러한 이유로 도금 후 시편 세척 과정에서, 미량의 $\mathrm{Al}_{2} \mathrm{O}_{3}$ 분말이 도금충 표면에서 이탈되었다.

\section{$3.2 \mathrm{Al}-\mathrm{Al}_{2} \mathrm{O}_{3}$ 입자의 면적점유율}

Fig. $5 \sim 8$ 은 $\mathrm{Ni}$ 도금욕에 $\mathrm{Al}$ 과 $\mathrm{Al}_{2} \mathrm{O}_{3}$ 분말을 혼합, 분 산시켰을 때 분산량과 전류밀도 변화에 따른 $\mathrm{Al}-\mathrm{Al}_{2} \mathrm{O}_{3}$ 입 자들의 면적점유율을 나타낸 것이다.

Fig. 5 의 $\mathrm{Ni}$ 도금욕에 Al을 $0.5 \mathrm{~g} / \ell$ 로 분산시킨 경우는 전류밀도 및 $\mathrm{Al}_{2} \mathrm{O}_{3}$ 의 분산량에 따라 $18 \sim 22 \%$ 의 낮은 면 적 점유율율 나타넸다. Fig. 6 8의 Al $1.25 \sim 5.0 \mathrm{~g} / \ell$ 분 산 조건의 경우는 전류밀도에 따라서 $20 \sim 90 \%$ 정도의 면 적 점유율을 나타냈다.

Fig. 7 과 8 의 Al $2.5 \mathrm{~g}, 5.0 \mathrm{~g} / \ell$ 분산 조건에서는 1 $15 \mathrm{~A} / \mathrm{dm}^{2}$ 의 전류밀도 구간내 $\mathrm{Al}_{2} \mathrm{O}_{3}$ 의 분산량에 따른 면적 점유율의 영향이 거의 없었으나 $20 \mathrm{~A} / \mathrm{dm}^{2}$ 에서는 $\mathrm{Al}_{2} \mathrm{O}_{3}$ 의 분산량이 감소할수록 도금층 표면 면적 점유율이 증가하였 다. 이와 같은 현상은 앞서 설명한 전류밀도 중가에 따른 $\mathrm{Al}$ 과 $\mathrm{Al}_{2} \mathrm{O}_{3}$ 입자들의 상호 간섭 작용에 기인한다. 반면, Fig. 6 의 Al $1.25 \mathrm{~g} / \ell$ 분산 조건에서는 $1 \mathrm{~A} / \mathrm{dm}^{2}$ 의 조건을 제외한 $5 \sim 20 \mathrm{~A} / \mathrm{dm}^{2}$ 의 조건에서는 $\mathrm{Al}_{2} \mathrm{O}_{3}$ 분산량에 따라 

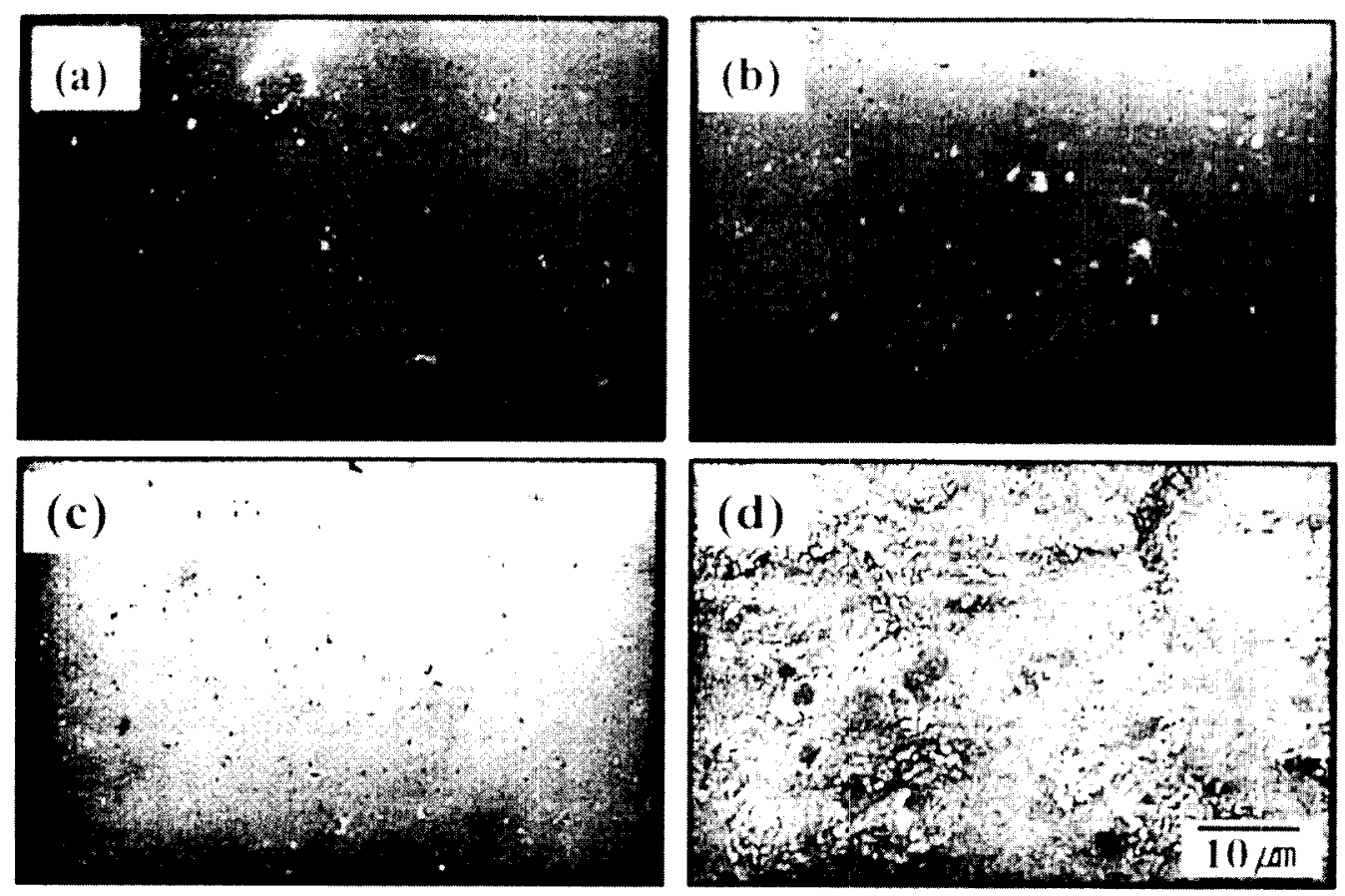

Fig. 4. Microscopic photographs (using image analyzer) of the coating surface with current density in the bath containing $5.0 \mathrm{~g} / \ell$ of $\mathrm{Al}_{2} \mathrm{O}_{3}$ (a) $20 \mathrm{~A} / \mathrm{dm}^{2}$ (b) $15 \mathrm{~A} / \mathrm{dm}^{2}$ (c) $10 \mathrm{~A} / \mathrm{dm}^{2}$ (d) $1 \mathrm{~A} / \mathrm{dm}^{2}$

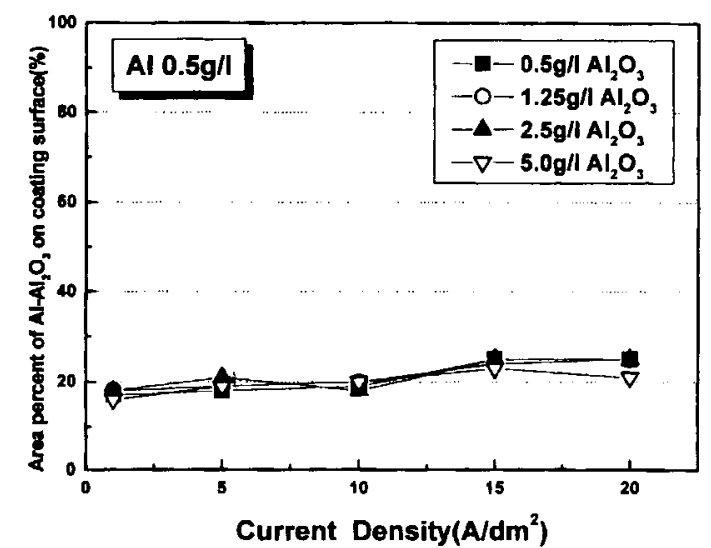

Fig. 5. Area percent of $\mathrm{Al}-\mathrm{Al}_{2} \mathrm{O}_{3}$ on coating surface with current density and $\mathrm{Al}_{2} \mathrm{O}_{3}$ loading in the bath containing $0.5 \mathrm{~g} / \ell$ of Al

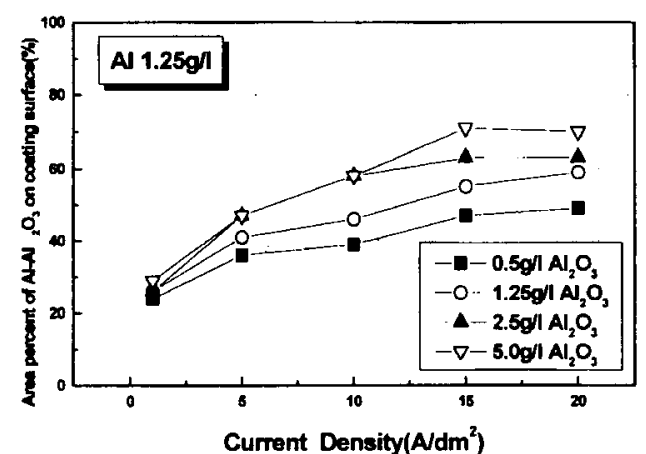

Fig. 6. Area percent of $\mathrm{Al}-\mathrm{Al}_{2} \mathrm{O}_{3}$ on coating surface with current density and $\mathrm{Al}_{2} \mathrm{O}_{3}$ loading in the bath $\mathrm{Ni}$ bath containing $1.25 \mathrm{~g} / \ell$ of $\mathrm{Al}$

다른 면적 점유율을 나타냈다.

즉, 다른 조건들과는 달리 $\mathrm{Al}_{2} \mathrm{O}_{3}$ 의 분산량이 증가함에 따

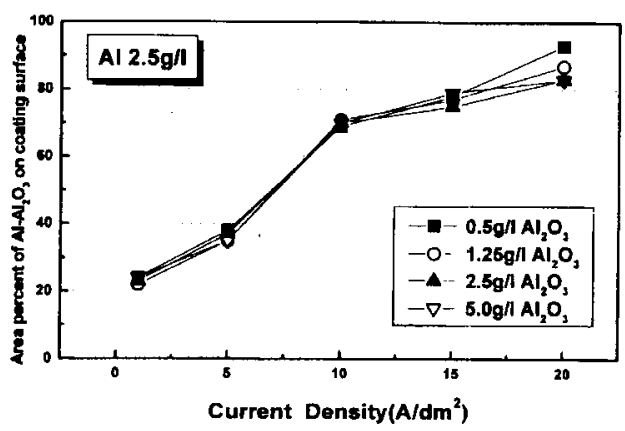

Fig. 7. Area percent of $\mathrm{Al}-\mathrm{Al}_{2} \mathrm{O}_{3}$ on coating surface with current density and $\mathrm{Al}_{2} \mathrm{O}_{3}$ loading in the bath containing $2.5 \mathrm{~g} / \ell$ of $\mathrm{Al}$

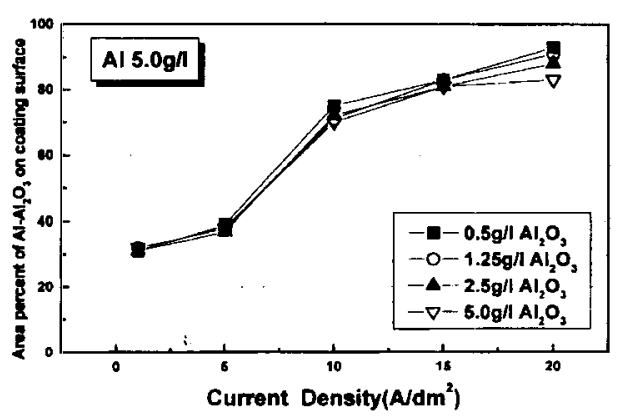

Fig. 8. Area percent of $\mathrm{Al}-\mathrm{Al}_{2} \mathrm{O}_{3}$ on coating surface with current density and $\mathrm{Al}_{2} \mathrm{O}_{3}$ loading in the bath containing $5.0 \mathrm{~g} / \mathrm{\ell}$ of $\mathrm{Al}$

라 면적 점유율이 증가하는 거동을 나타냈다. 이것은 $\mathrm{Ni}$ 도 금욕내에서 전도체인 $\mathrm{Al}$ 과 부도체인 $\mathrm{Al}_{2} \mathrm{O}_{3}$ 이 서로의 몸극 부착을 방해하지만 분산량이 적정 입계점에 이르면 서르의 간섭 효과가 상쇄될 수 있는 가능성을 시사하고 있다..$^{7.8}$ 

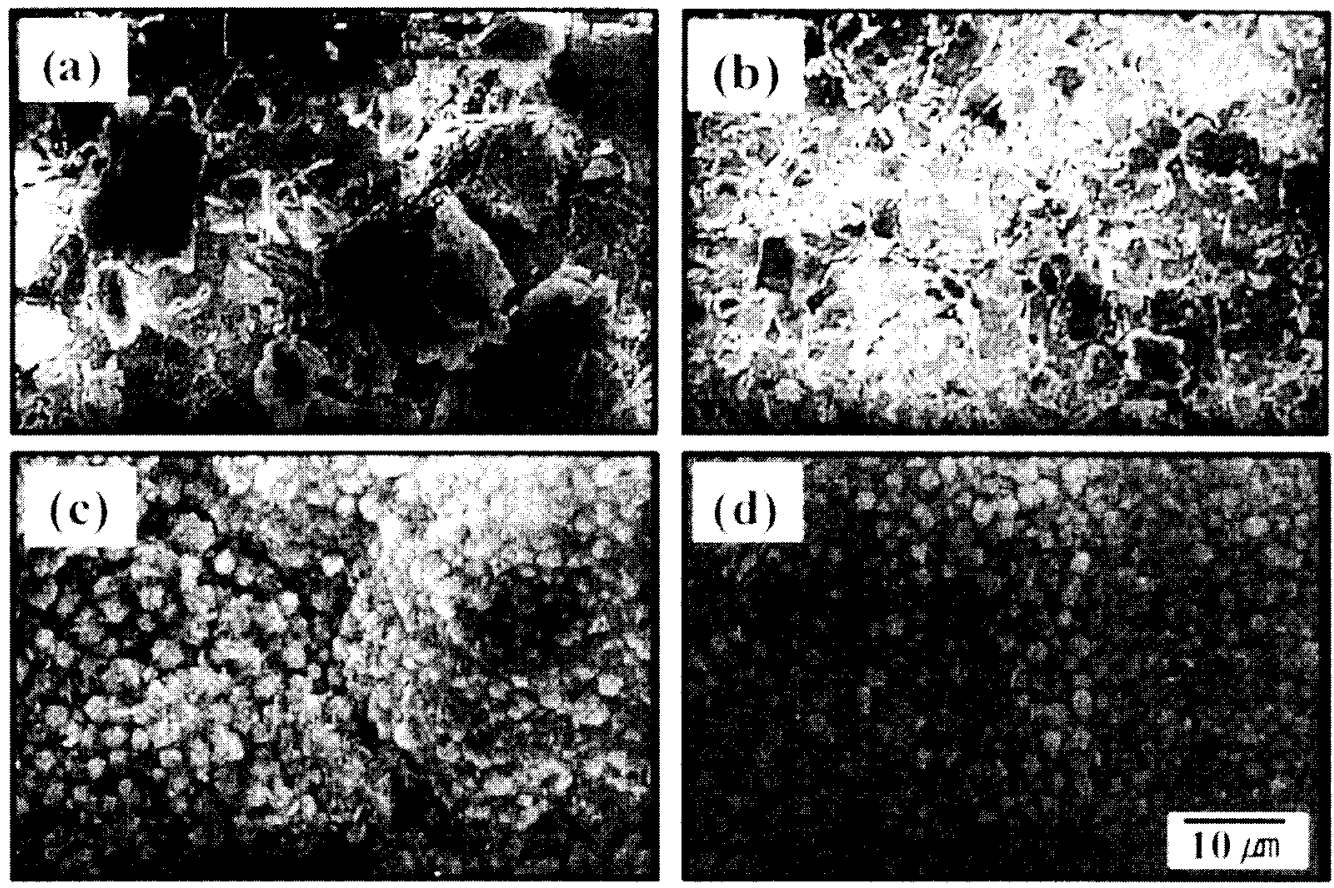

Fig. 9. SEM micrographs of the coating surface with $\mathrm{Al}_{2} \mathrm{O}_{3}$ loading in the bath containing $1.25 \mathrm{~g} / \ell$ of $\mathrm{Al}$ at $15 \mathrm{~A} / \mathrm{dm}^{2}$ (a) $0.5 \mathrm{~g} / \ell$ (b) $1.25 \mathrm{~g} / \ell$ (c) $2.5 \mathrm{~g} / \ell$ (d) $5 \mathrm{~g} / \ell$

Fig. 9는 $\mathrm{Ni}$ 도금욕에 $\mathrm{Al}$ 을 $1.25 \mathrm{~g} / \ell$ 분산시킨 후, $15 \mathrm{~A} / \mathrm{dm}^{2}$ 에서 $\mathrm{Al}_{2} \mathrm{O}_{3}$ 분산량에 따라 공석된 도금충 표면 형 상을 나타낸 것이다.

Fig. 9 (a) 에서는 Al입자들이 엉겨붙어서 형성된 조대한 입자들이 대부분을 차지하고 있다. (b) 의 $\mathrm{Al}_{2} \mathrm{O}_{3} 1.25 \mathrm{~g} / \ell$ 을 분산시킨 경우는 결정의 크기가 (a) 에 비해서는 작고 (c) 의 $\mathrm{Al}_{2} \mathrm{O}_{3} 2.5 \mathrm{~g} / \ell$ 을 분산시킨 경우는 미세한 입자들이 엉겨 붙어서 형성된 난알 형상의 결정으로 되어 있다. (d) 의 $\mathrm{Al}_{2} \mathrm{O}_{3} 5.0 \mathrm{~g} / \ell$ 을 분산시킨 경우는 표면이 평탄한 낟알 형 이 나타나며 표면 결정 입자들의 응집 현상이 감소하였다.

또한 도금욕 내에 $\mathrm{Al}$ 과 $\mathrm{Al}_{2} \mathrm{O}_{3}$ 를 단독으로 분산시켰을 경 우는 전류밀도 변화 및 분산량에 의해 도금충 표면 입자들 의 웅집현상이 발생하였다. 반면, $\mathrm{Al}-\mathrm{Al}_{2} \mathrm{O}_{3}$ 분산제를 혼합 하여 첨가할 경우, 특히 $\mathrm{Al}_{2} \mathrm{O}_{3}$ 량이 증가할수록 응집현상이 감소하고 결정립이 미세화 되었다.

\section{3 열처리후의 조직 변화}

Fig. 10 은 $\mathrm{Al}$ 과 $\mathrm{Al}_{2} \mathrm{O}_{3}$ 를 각각 $2.5 \mathrm{~g} / \ell$ 혼합, 분산하여 $15 \mathrm{~A} / \mathrm{dm}^{2}$ 전류밀도 조건에서의 도금충을 $600{ }^{\circ} \mathrm{C}$ 에서 열처 리한 표면의 형태를 비교한 것이다.

Fig. 10 (a) 는 1시간 동안 열처리 한 시편의 표면으로서 도금표면에서의 조밀한 입자들이 원자군화 되면서 길쭉한 모양의 세포 형상으로 변화되었다. Fig. 10 (b) 와 같이 열 처리 시간이 증가됨에 따라 조대화 되었으며, 30시간 열처 리 후에 얻어진 시편에서는 이러한 조대화 조직들이 사라지 면서 평탄한 도금표면이 형성되었으나 일부 피트 (pit) 가 관찰되었다. 이 피트는 장시간 동안의 열처리 과정에서 도 금표면에 부착된 $\mathrm{Al}$ 이 표면으로 확산했거나, $\mathrm{Al}_{2} \mathrm{O}_{3}$ 입자들이 도금표면에서 이탈되었기 때문으로 생각된다. Fig. 11 은
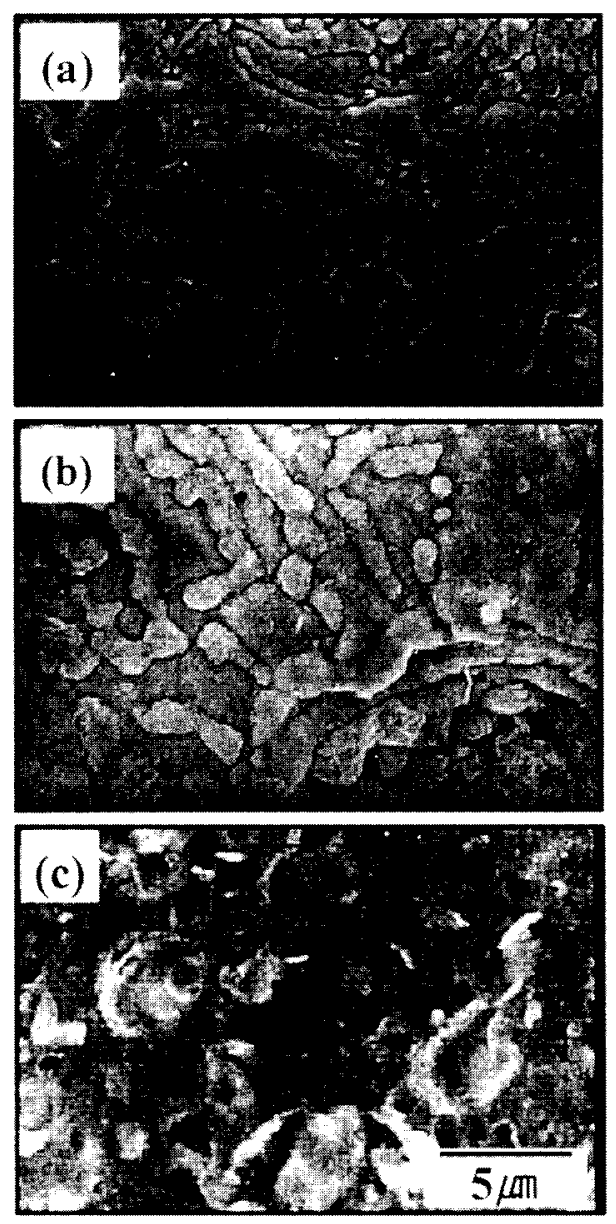

Fig. 10. SEM micrographs of the coating surface with annealing time at $600^{\circ} \mathrm{C}$ after electrodepositon as bath loading of $2.5 \mathrm{~g} / \mathrm{\ell}$ of $\mathrm{Al}$ and $2.5 \mathrm{~g} / \ell$ of $\mathrm{Al}_{2} \mathrm{O}_{3}$ at $15 \mathrm{~A} / \mathrm{dm}^{2}$ (a) $1 \mathrm{hr}$ (b) $10 \mathrm{hr}$ (c) $30 \mathrm{hr}$ 


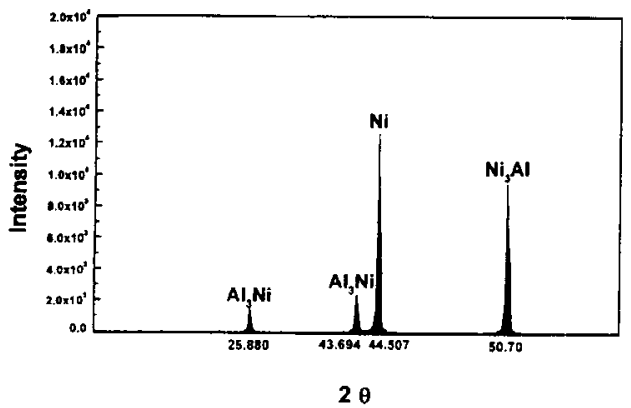

Fig. 11. X-ray diffraction patterns of the annealed deposit for $30 \mathrm{hr}$ at $600^{\circ} \mathrm{C}$ after electrodepositon as bath loading of $2.5 \mathrm{~g} / \ell$ of $\mathrm{Al}$ and $2.5 \mathrm{~g} / \ell$ of $\mathrm{Al}_{2} \mathrm{O}_{3}$ at $15 \mathrm{~A} / \mathrm{dm}^{2}$
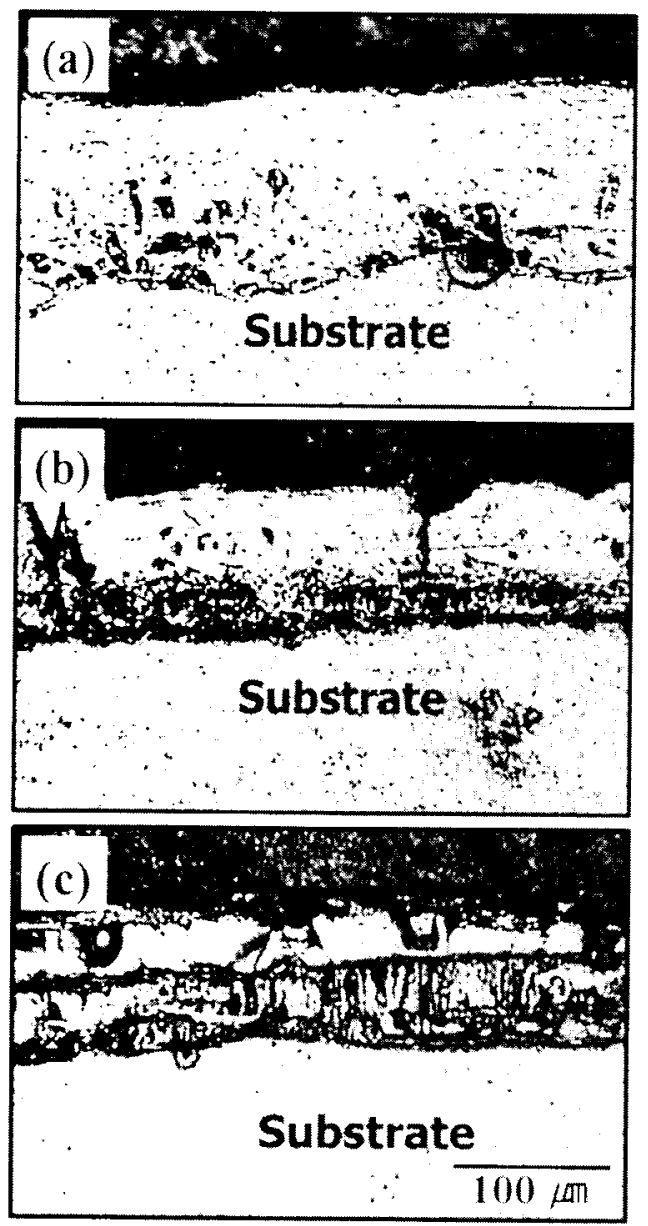

Fig. 12. Microscopic photographs of the coating surface with annealing time at $600^{\circ} \mathrm{C}$ after electrodepositon as bath loading of $2.5 \mathrm{~g} / \ell$ of $\mathrm{Al}$ and $2.5 \mathrm{~g} / \ell$ of $\mathrm{Al}_{2} \mathrm{O}_{3}$ at $15 \mathrm{~A} / \mathrm{dm}^{2}$ (a) $1 \mathrm{hr}$ (b) $10 \mathrm{hr}$ (c) $30 \mathrm{hr}$

Fig. 10 (c) 조건의 도금 표면에서 X선 회절분석 결과이다. 순수한 $\mathrm{Ni}$ 은 물론 $\mathrm{Al}_{3} \mathrm{Ni}, \mathrm{Ni}_{3} \mathrm{Al}$ 의 금속간 화합물 방위 피크가 관찰되었다. Fig. 12 는 열처리 시간에 따른 도금층 의 단면 양상을 상분석기로 관찰한 것이다.

그림에서와 같이 열처리 1 시간 조건에서는 도금층과 모 재와의 2 충이 확인되었다. 열처리 시간이 중가함에 따라 모 재와 도금충 사이에 내부 반응충이 형성되어 3 충이 관찰되 고, 내부 확산충의 두께도 증가하였다. 또한 Fig. 12 (c) 에
서는 내부 확산이 증가된 반면 상대적으로 도금충의 두께는 감소하였다. 이러한 결과를 퉁하여 $\mathrm{Ni}$ 도금욕에 분산제로 $\mathrm{Al}$ 과 $\mathrm{Al}_{2} \mathrm{O}_{3}$ 와 같은 분말 형태의 분산제를 사용하는 경우, 다음과 같은 부착 거동을 예상할 수 있다.

- $\mathrm{Ni}$ 전착 이온의 음극 환원과 동시에 분말이 음극에 부착 하는 형태

- 다른 하나는 미세 분말과 전착 이온이 입자 복합체를 형 성하여 부착되는 형태

주로 분말 형태의 분산제는 입자 복합체를 형성하지 않고 전착 이온과 분산 입자들이 독립적으로 부착 된 후, 음극 표면의 결정 성장에 영향을 미치지만,10 12) 전도체의 분산 입자 (예를 들어 Al) 의 크기가 매우 미세할 경우는 입자 복 합체 형성 이론도 가능한 것으로 보고 있다. ${ }^{3,9}$

특히 Al만을 분산시킨 조건에서 입자복합체가 형성되는 경우는 음극 표면에 입자들의 응집 현상이 현저히 감소된 다. 따라서 $\mathrm{Al}, 1 \sim 4 \mu \mathrm{m}$ 크기의 본 실험의 경우는 전착 이 온과 분산 입자의 독립적인 부착 형태로 예상되고 있다. 또 한 전착 이온과 분말 입자의 독립 부착계에서는 흡착강도 및 상호 졀합력이 적기 때문에 열처리에 의해 금속간화합물 을 도모하는 경우가 많다. 본 실험에서도 열처리를 통하여 도금충내에 혼재되어 있던 $\mathrm{Al}$ 과 $\mathrm{Ni}$ 의 금속간 화합물을 유 도할 수 있었다.

\section{4. 결 론}

와트 $\mathrm{Ni}$ 도금욕에서 $\mathrm{Al}, \mathrm{Al}_{2} \mathrm{O}_{3}$ 분말을 분산시켜, 전:착 이 온과 분산제와의 공석은 물론 열처리에 의한 조직 변화를 조사하여 다음과 같은 결론을 얻을 수 있었다.

1) $\mathrm{Ni}-\mathrm{Al}$ 의 경우 전류밀도와 $\mathrm{Al}$ 분산량이 증가할수록 도금면의 $\mathrm{Al}$ 의 부착 면적점유율은 증가하였다. 반면, $\mathrm{Ni}-$ $\mathrm{Al}_{2} \mathrm{O}_{3}$ 의 경우에는 분산량에는 비례하나, 전류밀도가 종가 할수록 부착 면적 점유율이 감소하였다. $\mathrm{Ni}$ 도금욕에 $\mathrm{Al}$ 과 $\mathrm{Al}_{2} \mathrm{O}_{3}$ 를 혼합, 분산시킨 경우는 $\mathrm{Al}$ 분산량 및 전류밀도에 비례하여 부착 면적점유율이 증가했다. 그러나 $\mathrm{Al}_{2} \mathrm{O}_{3}$ 분산 량을 중가시킬 경우는 동일한 전류밀도에서 $\mathrm{Al}-\mathrm{Al}_{2} \mathrm{O}_{3}$ 의 면적 점유율은 감소했다. 또한 $\mathrm{Al}$ 과 $\mathrm{Al}_{2} \mathrm{O}_{3}$ 입자들을 서로 공존시킴으로서 도금충 표면에서 $\mathrm{Al}$ 과 $\mathrm{Al}_{2} \mathrm{O}_{3}$ 입자들의 응 집현상이 감소하였다.

2) 분산도금 시편을 열처리를 함에 따라 $\mathrm{Al}, \mathrm{Al}_{2} \mathrm{O}_{3}$ 및 $\mathrm{Ni}$ 등 각각의 원소의 영향은 물론, 금속간화합물 $\left(\gamma^{\prime}, \gamma^{\prime}+\right.$ $\gamma$ ) 이 생성되었다.

\section{참 고 문 헌}

1. Hee-Taek Yum, Ju-Sung Lee, Electroplating \& Surface treatment, 162-172 (1988).

2. Celis, J.P. Roos, J.R. \& Buelens, C., A Mathematical model for the electrolytic codeposition of particles with a metallic matrix. J. Electrochem. Soc., 134, 1402-1408 (1987)

3. K. Barmak, S.W. Banovic, C.M. Peteronis, D.F. Susan \& A.R. Marder, Sturcture of electrodeposited graded 
composite coatings of $\mathrm{Ni}-\mathrm{Al}-\mathrm{Al}_{2} \mathrm{O}_{3}$. J. Microscopy, 185 265-274 (1997).

4. Argyrion. \& Spyrellis. N., Nickel electrodeposition from all sulfate and chloride baths. Texture and microhardness. Trans. Inst. Metal Finishing., 71, 83-84 (1993) .

5. Ding, X.M., Merk, N. \& Ilschner, B., Particle Volume Graded $\mathrm{Ni}-\mathrm{Al}_{2} \mathrm{O}_{3}$ and $\mathrm{Cu}-\mathrm{Al}_{2} \mathrm{O}_{3}$ composite deposits: production and performance. FGM '94. Proc. 3rd Int.l Symp. 365-370 (1995).

6. Yong Deuk Lee, Soo Ho Park. J. Kor. Inst. Met. and Mater., 6(1) (1993).

7. Iron and Steel 73, S1 193 (1987).

8. Sheet Metal Industrials (1978).
9. D.F. Susan, K. Barmak, A.R. Marder, Electrodeposited Ni-Al particle composite coatings, Thin Solid Films, 307, 133-140 (1997).

10. B.A. Movchan, A,V. Demchisin, Study of structure and properties of thick condensates of $\mathrm{Ni}, \mathrm{Ti}, \mathrm{W}, \mathrm{Al}_{2} \mathrm{O}_{3}$ and $\mathrm{ZrO}_{2}$, Phys. Met. Metallogr., 28, 83 (1969)

11. C.R.M. Grovenor, H.T.G. Hentzell, D.A. Smith, The development of grain structure growth of metallic films, Acta. Met. 32 (5) , 773-781 (1984).

12. T.R. Shives, L.C. Smith, Microindentation hardness measurements on metal powder particles, in: P.J. Blau, B.R. Lawn (Eds.), Microidentation Techniques in Materials Science and Engineering, ASTM, 243-257 (1985). 